\title{
Legality of Agent/Distributor Activities in The Perspective Of Civil Law
}

\author{
Bernard Nainggolan \\ Faculty of Law, Universitas Kristen Indonesia, Jakarta, Indonesia
}

\begin{abstract}
Agency/distributorship is a marketing tool in an economic system that is felt to be effective and efficient in relation to marketing networks. Normally, the regulation of agent and distributor activities has not been regulated in a specific formal law but is spread in various laws and regulations at the level of Regulations or Ministerial Decrees which do not specifically regulate agency or distributor activities. From the perspective of civil law, the validity of agency and distributor activities is based on Article 1338 of the Commercial Law Book. as the principle of freedom of contract which regulates the rights and obligations of parties in an agency/distributor agreement, namely between a business actor or principal and an agent or distributor.
\end{abstract}

Keyword: ministerial decrees, commercial law, business actor.

\section{INTRODUCTION}

One of the important problems in a marketing system is how a production of goods and/or services can reach consumers that is spread throughout remote locations far from the manufacturer. This problem in marketing discipline (economics) is known as distribution. Due to the expansion of the work area or business and marketing network, in practice, found various ways that can be used to overcome these problems, among others, by working on their own or by opening a branch (a subsidiary) and establishing a representative in a certain area so that it can represent its interests in the region.

Considering the limitations and efficiency, including in the financial sector, it is not uncommon for business actors to surrender their marketing activities to existing intermediaries or agents or distributors compared to opening their own marketing networks. Intermediary traders as rational marketers of various products from business actors have made the marketing process relatively more efficient and profitable for both business operators and consumers themselves.

For market conditions in Indonesia, the trader or intermediary institution referred to is known as an agency or distributorship agency. The appointment or appointment of an agent/distributor who acts represents the interests of the company in carrying out a purchase or sale (including promotion and market research activities) or producing a type of goods in a place, generally carried out with an agreement agreed by both parties. The company that makes the appointment is called the principal and the party who receives or approves the appointment is called an agent or distributor. 
The problem is that in the legal system in Indonesia, neither in civil law nor in commercial law is found and there are no specific arrangements regarding such agency/distributorship. However, in order to support the smooth and conducive climate for the business world, the government has issued Decree of the Minister of Industry No. 295 / M / SK / 1982 of 1982 concerning Sole Agency (Distributor). In terms of the legal basis for its regulation, it can cause problems in terms of binding power because it is only regulated in the form of a Decree of the Minister of Industry. Cannot comprehensively regulate matters relating to the activities of the agency or distributorship.

In terms of civil law, the validity of the legal relationship between business actors and agents or distributors is based on agreements, which is precisely in the perspective of civil law, agency or distributor agreements are not specifically known either in the Civil Law Book or in the Commercial Law Book. Therefore, this paper intends to discuss and analyze the existence of agency/distributor agreements in terms of civil law in the hope that it can be used as input for relevant parties for the efficient implementation of economic activities and create a conducive business climate.

\section{RESEARCH METHODOLOGY}

The research method used in this study is = juridical normative research method with descriptiveanalytical research specifications, namely research conducted based on normative rules that exist in legislation based on data and facts obtained through literature studies to then be analyzed descriptively based on regulations existing legislation. Therefore, the data analysis method used is a qualitative data analysis method.

\section{THEORETICAL REVIEW}

In the perspective of economics, it can be stated that the working patterns of agents and distributors, is the pattern of marketing work, which is a mechanism leading to the main target of consumers. Basically there are three marketing channels based on formal classification, which are specifically based on the recognition of dependency as follows: 1). Vertical marketing system; 2). Free path; and). Single transaction path

In a vertical marketing system, there is always dependence on one another and one is considered and must have more authority and be considered as a leader. In this case it is usually the principal and occurs in a single business and occurs on a formal contract basis. So a legal interdependence relationship is formally promised in this system and the legal relationship is relatively fixed for the long term.

Free path system, there is no interdependence. The contract period is relatively short (one year) and the terms of the agreement are conditions of the transportation industry and can be combined with a vertical system. A single transaction system, is marketing based on negotiations, so there is no major role in the marketing function.

In the legal literature in Indonesia, between agency and distributor, it cannot be separated in principle so that many parties formulate that the agency agreement is equated with the distributor agreement by stating the agency/distributorship agreement. This is due to the fact that between agents and distributors, although basically, they have different meanings, they have the same or 
Nainggolan, B. (2020). Legality of Agent/Distributor Activities in The Perspective of Civil Law. Advances in Social Sciences Research Journal, 7(4) 248-253.

almost the same function, thus providing intermediary services from producers/principals to consumers.

I Ketut Oka Setiawan said that a distributor is an intermediary person/company who is given the right by a factory or a large trader to sell a kind of goods in a city/region. Trade agents are not contracted workers as regulated in the Book of Commercial Civil Law. He can hold several factories or large traders, where for this agency he receives a specified amount of money for each month from the provision of goods sales. If in a country, there are many general agents or large agents.

Eric Rasmusen said that agency deals with situations in which one person -- the principal-- uses another person -- the agent-- to act on his behalf. Sometimes the acts of the agent are attributed legally to the principal, sometimes not. Delineating the conditions under which each is true are what make up the law of agency. In line with George M. Cohen who said that agency involves relationships among three parties: the principal, the agent, and the third party. A principal is an owner of property: an asset or a collection of assets. Assets can be physical, but in many cases they are intangible, such as information (e.g., intellectual property), a legal right or interest (e.g., contracts or financial assets), or reputation (good will).

In economics, an agent or distributor is a distribution channel as is the case with brokers and commissioners in the Commercial Code. Starting from the understanding and function of brokers and commissioners who in general are intermediaries who provide services from one party to another party with unequal responsibilities.

Achmad Ichsan stated that agency is an act of involving others to carry out an act not in civil law. Furthermore, H. Tirtaamidjaja formulated that an agency (agency) is the same as a business agent is a person who has a company to provide intermediaries for certain agreements on behalf of the principal.

While the definition of distributor according to Black's stated is any individual, partnership, corporation, association or other legal relationship which stands between the manufacturer and the retail seller in purchase, consignments or contracts for the sale of consumer goods a wholesaler.

In terms of regulation, it can be stated that there is no (formal) law specifically regulating issues related to distributor activities/agreements, except in the form of a Decree of the Minister of Industry, namely No. 295 / M / SK / 1982 of 1982 concerning Sole Agency (Distributor). In terms of the basic legal relationship between the parties between business actors and agents or distributors, the general provisions are only found in Book III of the Book of Commercial Civil Law on Engagement.

The various laws and regulations below, which recognize and refer to the words agents and distributors, but do not specifically regulate substantially can be grouped as follows:

1. Regulatory groups regarding agents or distributors that have to do with pharmacy and cosmetics, namely:

a) Regulation of the Minister of Health of the Republic of Indonesia No. 238 / Menkes / IX / 1976 concerning wholesalers and medical devices. In this regulation, there was no 
agency content, but only mentioned through Article 10 the term wholesaler who cannot sell drugs.

b) Decree of the Minister of Health of the Republic of Indonesia No. 339 / Men.Kes / SK / 1988. In its decision number (4) states that PT. Kimia Farma as executor and distributor of health Inpres medicines lists A, B1 and B at a fixed price.

2. Group of regulations concerning Indonesian fertilizer agents or distributors, namely Minister of Trade Decree No. 66 / Kp / III / 1973 concerning the Agency for Sole Production of foreign fertilizers, which in article 3 explicitly states that in the marketing of fertilizers in Indonesia, it is carried out through designated agents.

3. Regulatory groups that are related to foreign investment, namely:

a) PP No. 36 of 1977 concerning the termination of foreign business activities in the field of trade. In this Government Regulation, it is stated that in the possession of a business, if there is an overseas holding company, it can appoint national traders as distributors or agents. Therefore, this government regulation does not distinguish what is meant by agents and distributors.

b) Decree of the Minister of Trade of the Republic of Indonesia No. 78 / Kp / III / 1978 concerning Provisions for Business Licensing of Representatives of Foreign Trade Companies. In this decree, three types of agents are mentioned, namely: -). sales agent (selling agent); -). factory agents (manufactures agents); and; -). buying agent

4. Group of regulations relating to motor vehicles and heavy equipment, namely:

a) Minister of Trade Decree No. 315 / Kp / XII / 1970 concerning the import and distribution of large equipment (including earthmoving and road construction equipment) must go through a brand holder or sole agent.

b) Presidential Decree No. 15 of 1972 concerning Simplification of the Provisions for the Recognition and Reduction of the Recognition of Single Agency Motorized Vehicles and large equipment and the agency of large equipment and the sole agency of electronic devices and household electrical appliances. This Presidential Decree formulates what is meant by a single agent, namely a national company appointed by an overseas principal who produces goods with a particular brand or with a principal of a particular brand holder as the only company to import, promote, distribute and carry out services for all intended after-sales of goods to all parts of Indonesia for a certain period of time. In this case, it means that the agent's duties are expanded with the assignment of tasks for the field of promotion and after-sales.

c) Decree of the Minister of Industry No. 295 / M / SK / 7/1982 concerning Agency Provisions.

d) Decree of the Minister of Industry No. 428 / M / SK / 7/1987 concerning Simplification of the Provisions for the Recognition and Reduction of Single Agency Motorized Vehicles and large and single agency equipment for electronic devices and electrical appliances for households.

5. The group of regulations that have to do with insurance, namely Government Regulation (PP) No. 73 of 1992 concerning Insurance which in article 17 states that each insurance agent can only be an agent of one insurance company. 


\section{DISCUSSION}

\section{The legality of Agency / Distributor Activities in the Civil Law Perspective}

In terms of regulation, the agency/distributor agreement includes an onbenoemnde contract type which is a type of agreement that is not specifically regulated in a special section of Book III of the Commercial Law Book, but grows and develops in the practice of community economic activities. This is based on the principle of freedom of contract contained in article 1338 of the Commercial Law Book which stipulates that all treaties made legally will act as laws for those who make them.

There is no specific regulation that requires that an agency or distributorship agreement be made in the form of a notary deed so that in practice it is not uncommon that the agreement is made only with a deed under the hand. In fact, not infrequently agreements are prepared unilaterally by the principal with standard terms and conditions in the form of standard agreements.

The relationship between producers/principals and agents gives birth to a legal relationship between the parties on the basis of the principles of contractual law and by observing and upholding the principle of freedom of contract, so that the relationship is a mutually beneficial relationship with one another.

The legal relationship between the principal parties and the agent/distributor places both parties in a theoretically equal/balanced position and in a position of facing each other. Principals as the first party have certain rights and obligations and authorities for the goods/services of their products. While agents/distributors also have certain rights and obligations and authority for marketing, and distribution of certain goods/services provided by the principal.

There are indicators that can distinguish agents from distributors, namely regarding legal relations with third parties. As described earlier, a person or legal entity can be called an agent if in the case of dealing with or taking legal action with a third party carried out on behalf of the principal, while being called a distributor if in the case of dealing with a third party carried out on his own behalf.

If a product marketed by a distributor is carried out by way of buying, then what appears in the relationship with a third party is that the agent/distributor closes the agreement for and on his own behalf because the ownership of the goods has been transferred to the distributor/agent company. If the goods are obtained by being authorized to sell by the principal, it is certain that the agent/distributor in matters relating to third parties is carried out for and on behalf of the principal.

If the agent closes the agreement with a third party for and on his own behalf means the principal will not be responsible for product defects or anything that arises as a result of the closure of the agreement. If the agent is responsible for third parties for product defects, it means that there is a possibility for agents to be sued by third parties. After-sales service and responsibility/guarantee for goods that have been purchased by consumers/users is one form of principal responsibility. However, the implementation of such principal responsibilities is carried out in part by agents/distributors. In providing after-sales services, agents/principals usually have or provide experts even this is one of the conditions for the appointment of an agent/distributor. 
Principal responsibilities aside from providing after-sales service at the same time together with the dependents/warranty on the product so that if the product is damaged before the warranty period is not due to the fault of the buyer, the principal is still doing repairs or if necessary returning goods with a new replacement (contained in computer electronic products).

\section{CONCLUSION}

Until now there has been no specific regulation relating to agency/distributor agreements, except in a variety of Regulations or Ministerial Decrees which do not clearly distinguish the position, duties and functions between agents and distributors. From the perspective of civil law, the agency/distributor activity is an engagement legal relationship originating from an agreement between the principal and the agent or distributor and is valid according to Article 1338 of the Commercial Law Book.

\section{SUGGESTION}

To create a conducive climate in the field of economic activity, especially marketing activities, it is necessary to specifically regulate everything related to agency and distributor activities by providing differences between agents and distributors through formal laws.

\section{References}

\section{Books}

I Ketut Oka Setiawan, Lembaga Keagenan Dalam Perdagangan Dan Pengaturannya di Indonesia, Indohill. Co, Jakarta, 1995.

Subekti R, Hukum Perjanjian, PT. Intermassa, Jakarta, 1985.

Achmad Ichsan, Hukum Perdata I B, PT. Pembimbing Masa, Jakarta, 1967.

H. Tirtaamidjaja, Pokok-Pokok Hukum Perniagaan, Djambatan, Jakarta, 1970.

CST. Kansil, Pokok-Pokok Hukum Dagang Indonesia, PT. Pradnya Paramita, Jakarta, 1988.

\section{Laws and regulations}

Subekti R dan Tjitrosudibio, Kitab Undang Undang Hukum Perdata, Pradnya Paramita, Jakarta, 1987.

Subekti R dan Tjitrosudibio, Kitab Undang Undang Hukum Dagang, Pradnya Paramita, Jakarta, 1982.

\section{Journals}

Eric Rasmusen, Agency Law and Contract Formation, 2001, p. 1. Retrieved from http://www.law.harvard.edu/programs/olin_center/papers/pdf/323.pdf

George M. Cohen, Law and Economics of Agency and Partnership, University of Virginia School of Law. 2018. p. 400. Retrieved from https://ssrn.com/abstract=3208640 